Research article

Open Access

\title{
Biologic activity and safety of belimumab, a neutralizing anti-B-lymphocyte stimulator (BLyS) monoclonal antibody: a phase I trial in patients with systemic lupus erythematosus
}

\author{
Richard Furie', William Stohl2, Ellen M Ginzler ${ }^{3}$, Michael Becker ${ }^{4}$, Nilamadhab Mishra5, \\ Winn Chatham ${ }^{6}$, Joan T Merrill7, Arthur Weinstein ${ }^{8}$, W Joseph McCune ${ }^{9}$, John Zhong ${ }^{10}$, \\ Wendy Cai11, William Freimuth ${ }^{12}$ for the Belimumab Study Group
}

\author{
1Division of Rheumatology and Allergy-Clinical Immunology, North Shore Long Island Jewish Health System, Marcus Avenue, Lake Success, New \\ York 11042, USA \\ ${ }^{2}$ Division of Rheumatology and Immunology, University of Southern California Keck School of Medicine, Zonal Avenue, Los Angeles, California 90033 , \\ USA \\ 3Division of Rheumatology, SUNY Downstate Medical Center, Clarkson Avenue, Brooklyn, New York 11203, USA \\ ${ }^{4}$ Department of Medicine/Section of Rheumatology, The University of Chicago Hospitals, South Maryland Avenue, Chicago, Illinois 60637, USA \\ ${ }^{5}$ Section of Rheumatology \& Clinical Immunology, Wake Forest University Health Sciences, Medical Center Boulevard, Winston-Salem, North \\ Carolina 27157, USA \\ ${ }^{6}$ Division of Immunology and Rheumatology, University of Alabama at Birmingham, 510 20th Street, Birmingham, Alabama 35294, USA \\ ${ }^{7}$ Department of Medicine, Clinical Pharmacology Research Program, Oklahoma Medical Research Foundation, 825 NE 13th Street, Oklahoma City, \\ Oklahoma 73104, USA \\ ${ }^{8}$ Department of Medicine, Section of Rheumatology, Washington Hospital Center, Irving Street NW, Washington, Distric of Columbia 20010, USA \\ 9Division of Rheumatology, University of Michigan Health System, E Medical Center Drive, Taubman Center, Ann Arbor, Michigan 48109, USA \\ ${ }^{10}$ Biostatistics, Human Genome Sciences, Inc., Shady Grove Road, Rockville, Maryland 20850, USA \\ ${ }^{11}$ Pharmacology, Pharmacokinetics \& Toxicology, Human Genome Sciences, Inc., Shady Grove Road, Rockville, Maryland 20850, USA \\ ${ }^{12}$ Clinical Research, Human Genome Sciences, Inc., Shady Grove Road, Rockville, Maryland 20850, USA
}

Corresponding author: Richard Furie, furie@nshs.edu

Received: 15 Apr 2008 Revisions requested: 14 May 2008 Revisions received: 25 Aug 2008 Accepted: 11 Sep 2008 Published: 11 Sep 2008

Arthritis Research \& Therapy 2008, 10:R109 (doi:10.1186/ar2506)

This article is online at: http://arthritis-research.com/content/10/5/R109

(c) 2008 Furie et al.; licensee BioMed Central Ltd.

This is an open access article distributed under the terms of the Creative Commons Attribution License (http://creativecommons.org/licenses/by/2.0), which permits unrestricted use, distribution, and reproduction in any medium, provided the original work is properly cited.

\begin{abstract}
Introduction This trial evaluated the safety, biologic activity, and pharmacokinetics of belimumab, a fully human monoclonal antibody that inhibits the biologic activity of the soluble form of the essential B-cell survival factor B-lymphocyte stimulator (BLyS) in patients with systemic lupus erythematosus (SLE).

Methods Seventy patients with mild-to-moderate SLE were enrolled in a phase I, double-blind, randomized study and treated with placebo $(n=13)$ or belimumab $(n=57)$ at four different doses $(1.0,4.0,10$, and $20 \mathrm{mg} / \mathrm{kg})$ as a single infusion or two infusions 21 days apart. Patients were followed for 84 to 105 days to assess adverse events, pharmacokinetics, peripheral blood B-cell counts, serology, and SLE disease activity. Data from the study were summarized using descriptive statistics. $\chi^{2}$ type tests were used to analyze discrete variables. The Kruskal-Wallis test, the Wilcoxon test, and the analysis of covariance were used to analyze the continuous variables, as
\end{abstract}

appropriate. The analysis was performed on all randomized patients who received study agent.

Results The incidences of adverse events and laboratory abnormalities were similar among the belimumab and placebo groups. Belimumab pharmacokinetics were linear across the 1.0 to $20 \mathrm{mg} / \mathrm{kg}$ dose range. Long terminal elimination half-life ( 8.5 to 14.1 days), slow clearance $(7 \mathrm{ml} /$ day per $\mathrm{kg}$ ), and small volume of distribution (69 to $112 \mathrm{ml} / \mathrm{kg}$ ) were consistent with a fully human antibody. Significant reductions in median percentages of $\mathrm{CD} 2 \mathrm{O}^{+} \mathrm{B}$ cells were observed in patients treated with a single dose of belimumab versus placebo (day $42: P=$ 0.0042 ; and day 84: $P=0.0036$ ) and in patients treated with two doses of belimumab versus placebo (day 105: $P=0.0305$ ). SLE disease activity did not change after one or two doses of belimumab.

AE: adverse event; ANA: anti-nuclear antibody; ANC: absolute neutrophil count; BlyS: B-lymphocyte stimulator; dsDNA: double-stranded DNA; ELISA: enzyme-linked immunosorbent assay; HAHA: human anti-human antibody; mAb: monoclonal antibody; PGA: Physician's Global Disease Assessment; SELENA: Safety of Estrogens in Lupus Erythematosus National Assessment; SF-36: 36-item Short Form; SLE: systemic lupus erythematosus; SLEDAI: Systemic Lupus Erythematosus Disease Activity Index; TNF: tumor necrosis factor. 
Conclusions Belimumab was well tolerated and reduced peripheral B-cell levels in SLE patients. These data support further studies of belimumab in autoimmune disorders.
Trial Registration NCT00657007 [clinicaltrials.gov].

\section{Introduction}

Systemic lupus erythematosus (SLE) is typified by the production of autoantibodies, such as anti-double-stranded DNA (anti-dsDNA) antibodies and anti-nuclear antibodies (ANAs). Although the disease is characterized by the presence of autoreactive $T$ lymphocytes, there is growing evidence that $B$ cells play a central role in the pathogenesis of SLE [1-3]. Hyperactive $B$ cells may mediate disease by promoting the expansion of autoreactive CD4 ${ }^{+} \mathrm{T}$ cells via antigen presentation [1-3]. The frequency of circulating plasma cells correlates with SLE disease activity and with the titer of anti-dsDNA autoantibodies [4]. Therefore, B-cell and plasma cell depletion may be an appropriate therapeutic approach in the treatment of SLE.

B-lymphocyte stimulator (BLyS) is a member of the tumor necrosis factor (TNF) ligand superfamily of cytokines that is expressed and secreted by monocytes, macrophages, dendritic cells, and granulocyte colony-stimulating factor activated neutrophils $[5,6]$. BLyS exists in both membrane-bound and soluble forms. The biologically active, soluble form of BLyS is enzymatically cleaved from the cell membrane and can bind to any of three receptors: TACl (transmembrane activator and calcium-modulator and cyclophilin ligand interactor) [7]; BCMA (B-cell Maturation Antigen) [8]; and BAFF-R (B-cell lymphocyte activating factor receptor)/BLyS receptor 3 $[9,10]$, localized primarily on B lymphocytes. BLyS contributes to B-cell proliferation and differentiation, and it is important in immunoglobulin class switching [5,11]. Constitutive overexpression of BLyS in transgenic mice results in the development of an autoimmune-like disease that is characterized by hypergammaglobulinemia, autoantibody production, and glomerulonephritis $[8,12,13]$. In murine lupus, treatment with a BLyS antagonist significantly reduces the occurrence of proteinuria and prolongs survival $[8,14]$. Moreover, elevated BLyS blood levels have been found in some patients with SLE $[15,16]$, and observational studies demonstrated that BLyS concentrations change over time in the majority of SLE patients [17,18]. Increases in BLyS levels correlated with increased disease activity and were predictive of future disease activity, suggesting that BLyS may be a biomarker for SLE [17].

Belimumab (LymphoStat-B; Human Genome Sciences, Inc., Rockville, MA, USA) is a recombinant, fully human, $\lg _{1 \lambda} \mathrm{mAb}$ that binds to soluble BLyS with high affinity. The antibody exerts its biologic activity by preventing the binding of BLyS to its receptors [19]. Belimumab potently inhibits BLyS-induced proliferation of $\mathrm{B}$ cells in vitro and prevents human BLySinduced increases in splenic B-cell numbers and serum $\lg A$ tit- ers in mice [19]. In cynomolgus monkeys treated with belimumab, reductions as great as $75 \%$ were observed in the number of lymphoid tissue and peripheral blood CD20+ $\mathrm{B}$ cells and CD21+ plasmacytoid cells [20]. Importantly, intravenous doses of up to $50 \mathrm{mg} / \mathrm{kg}$ delivered every 2 weeks over 6 months were well tolerated in cynomolgus monkeys. On discontinuation of belimumab in cynomolgus monkeys, the numbers of peripheral blood CD20+ B cells recovered to normal levels within 3 to 5 months [20]. Because belimumab has the potential to provide therapeutic benefit in SLE patients, we conducted a phase I study of belimumab in SLE patients with stable, mild to moderate disease activity and demonstrated its safety, biologic activity, and pharmacokinetics.

\section{Materials and methods Patients}

Patients aged 18 years or older with SLE, as defined by the American College of Rheumatology criteria [21], were enrolled in the trial. Eligible patients had stable SLE disease activity, as clinically judged by the principal investigator, for at least 2 months before screening and were either maintained with no medication or with a stable treatment regimen of lowdose ( $\leq 15 \mathrm{mg}$ ) prednisone, antimalarials, nonsteroidal antiinflammatory drugs, methotrexate, azathioprine, or mycophenolate mofetil. Patients were required to have a history of measurable anti-dsDNA, anti-Smith, anti-ribonucleoprotein, anti-cardiolipin, anti-Sjögren's syndrome-A/Ro, or anti-Sjögren's syndrome-B/La autoantibodies. Patients with active lupus nephritis requiring hemodialysis, cyclophosphamide, or high-dose (>60 mg) prednisone, or who had received leflunomide, cyclosporin, intravenous gammaglobulin, or plasmapheresis within 6 months of screening were not eligible. Patients with active central nervous system lupus within 6 months of screening, a history of renal transplant, hypogammaglobulinemia or $\lg A$ deficiency, evidence of clinically significant nonSLE-related acute or chronic disease, or a history of any serious infection within 4 weeks of study entry were also excluded. Pregnant or nursing patients were ineligible for inclusion in the study, and adequate contraceptives were required in participating patients. The protocol was approved by each center's institutional review board, and all patients provided written informed consent.

\section{Study design and treatment}

This was a phase I, multicenter (20 sites), randomized, doubleblind, placebo-controlled, dose-escalation study of belimumab in patients with SLE. Patients received belimumab 1.0, 4.0, 10 , or $20 \mathrm{mg} / \mathrm{kg}$ or placebo administered intravenously over at least 2 hours. Patients in cohorts 1 to 4 received a single dose 
of belimumab or placebo, whereas patients in cohorts 5 to 8 received two identical doses of belimumab or placebo 3 weeks apart.

Permission to escalate the dose was granted by the Human Genome Sciences Review Committee. The primary safety end-point for dose escalation was the incidence of grade 3 (severe) or 4 (life-threatening) adverse events (AEs). Dose escalation and initial dosing of the double-dose cohorts were not allowed if two or more patients in a cohort experienced a grade 3 or $4 \mathrm{AE}$, including hypogammaglobulinemia.

\section{Safety assessment}

AEs were coded on the basis of the Medical Dictionary for Regulatory Activities terminology version 6.0 and were graded for severity according to the National Institutes of Health Division of Microbiology and Infectious Diseases Adult Toxicity Tables (Version May 2001). Adverse events and serious AEs were considered treatment emergent if they occurred within 84 days after the final dose of study agent (day 84 for singledose cohorts and day 105 for double-dose cohorts). Hematology, clinical chemistry, and urinalysis panels were assessed on days $0,2,7,14,28,42,56$, and 84 for patients in the singledose cohorts, and on days $0,2,7,14,21,23,28,35,49,63$, 77 , and 105 for patients in the double-dose cohorts. In a 4week, preclinical monkey toxicology study, one (asymptomatic) animal treated with high dose belimumab $(50 \mathrm{mg} / \mathrm{kg}$ ) was found at terminal necropsy to have multiple splenic abscesses that might have existed before treatment. Therefore, abdominal computed tomography scans with oral contrast were performed randomly in half of the patients in each cohort at screening and 28 days after the last dose to evaluate the risk for abdominal infection. It should be noted that in a subsequent 26 -week, multiple-dose (0 to $50 \mathrm{mg} / \mathrm{kg}$ ) monkey toxicology study, belimumab was well tolerated and no abscesses or other toxicities were identified [20].

\section{Immunogenicity assessment}

Blood samples were evaluated for anti-belimumab antibodies on day 0 before dosing and on days 14, 28, 56, and 84 for patients in single-dose cohorts; samples were obtained in the double-dose cohorts on days 0 and 21 before dosing and on days $14,35,49,77$, and 105 . Samples were allowed to clot for 30 minutes at room temperature, centrifuged at 1,000 to $1,300 \mathrm{~g}$ for 10 to 15 minutes, and the serum was decanted and immediately frozen. The presence of anti-belimumab antibodies was determined using two screening ELISAs. The first assay was performed using the Fab portion of belimumab immobilized to a microtiter plate. Captured anti-belimumab antibodies were detected with horseradish peroxidase-conjugated goat anti-human $\lg \mathrm{G}+\lg \mathrm{A}+\lg \mathrm{M}$ antibody and were quantitated by color conversion of tetramethylbenzidine. The second assay was performed using belimumab (whole antibody) immobilized to a microtiter plate. Captured anti-belimumab antibodies were detected with horseradish peroxidase- conjugated goat anti-human $\kappa$ chain specific antibody, and they were quantitated by color conversion of tetramethylbenzidine. A serum sample was considered potentially positive for anti-belimumab if the mean $A_{450}$ value of the postdose sample was at least twofold greater than the mean $A_{450}$ value of the predose sample.

Samples that had tested positive in either screening assay were then examined in a neutralization assay. Predose and postdose samples were serially diluted and added to microplates coated with immobilized belimumab, followed by the addition of europium-labeled BLyS. Anti-belimumab antibody present in the sample would bind to the immobilized belimumab, and competitively inhibit binding of europium-labeled BLyS. Europium-labeled BLyS binding was quantitated by time-resolved fluorometric spectroscopy at $615 \mathrm{~nm}$ (excitation at $340 \mathrm{~nm}$ ). A sample was considered to contain neutralizing anti-belimumab antibody if the mean postdose signal was statistically lower than the mean predose signal $(P<0.01$, unpaired one-tailed $t$-test).

\section{Systemic lupus erythematosus disease activity assessment}

Primary outcomes for clinical disease activity included the Safety of Estrogens in Lupus Erythematosus National Assessment (SELENA) Systemic Lupus Erythematosus Disease Activity Index (SLEDAI) [22], Flare Index [22,23], and the Physician's Global Disease Assessment (PGA). Proper use of these instruments was reviewed at the investigator's meeting. The PGA was based on a visual analog scale ranging from 0 (no disease activity) to 3 (severe disease activity). The Short Form-36 (SF-36; version 2) Health Survey, a self-administered survey, was incorporated to assess quality of life. All clinical disease activity measurements were assessed on days 0,28 , 56 , and 84 for patients in the single-dose cohorts, and on days $0,21,49,77$, and 105 for patients in the double-dose cohorts.

\section{Pharmacokinetics}

Serum concentrations of belimumab were determined by ELISA. BLyS-reactive belimumab was captured from diluted human serum onto BLyS-coated microtiter plates. Captured belimumab was detected using peroxidase-conjugated secondary mouse monoclonal anti-human $\lg G$ antibody. The lower limit of quantitation for this ELISA assay is $138.5 \mathrm{ng} / \mathrm{mL}$ of belimumab in 100\% human serum.

\section{Biologic marker assessment}

Biologic marker assessments included CD20+ B cells and CD138+ plasmacytoid cells, anti-dsDNA antibodies, ANAs, immunoglobulins ( $\lg G$, $\lg M$, $\lg E$, and $\lg A$ ), and complement (C3 and C4). Anti-dsDNA antibodies and ANAs were measured by Farr assay (Specialty Laboratories, Santa Monica, CA, USA) and indirect fluorescent antibody assay (FOCUS Diagnostics, Herndon, VA, USA), respectively. Immunoglobulins, $\mathrm{C} 3$, and $\mathrm{C} 4$ were measured by nephelometry (FOCUS 
Diagnostics). Blood samples were drawn at screening (day 0 ) and on days $14,28,42,56$, and 84 for patients in single-dose cohorts, and at screening and on days $0,14,21,35,49,63$, 77 , and 105 for patients in double-dose cohorts. Absolute counts of $B$ cells and plasmacytoid cells were calculated on the basis of white blood cell counts multiplied by the percentage of lymphocytes and the percentage of cells staining for the CD20 and CD138 markers, respectively, as determined by fluorescence-activated flow cytometry. BLyS levels could not be measured because the presence of belimumab in the blood interfered with the detection of BLyS.

\section{Statistical methods}

Data from the study were summarized using descriptive statistics. $\chi^{2}$ type tests were used to analyze discrete variables. For continuous variables, the Kruskal-Wallis test was used to examine the difference across all treatment groups, and the Wilcoxon test was used to compare the differences between placebo and each of the belimumab-treated groups. An analysis of covariance was used to analyze the continuous variables if there was a significant difference in the variable at baseline. The analysis was performed on a modified intent-to-treat population, defined as the subset of all randomized patients who received study agent. All statistical analyses were performed using SAS (SAS Institute Inc., Cary, NC, USA), WinNonlin (Pharsight Corp., Mountain View, CA, USA), or R statistical packages.

\section{Results \\ Patients}

A total of 70 patients were enrolled in this study (Table 1). The majority (91\%) of patients were female, and the median age was 38.5 years (range 22 to 80 years). Half of the patients were white, and $47 \%$ of patients were African American; all treatment groups included patients of Hispanic origin. The median duration of disease was 6.5 years (range 0.3 to 37.7 years). The majority of patients had disease manifestations that included ANA positivity (97\%), immunologic disorder (89\%), arthritis (87\%), hematologic disorder (64\%), or malar rash (56\%) at the time of diagnosis. At baseline, $90 \%$ of the patients had ANA titers of 1:40 or greater, $60 \%$ were antidsDNA antibody positive ( $\geq 5 \mathrm{IU} / \mathrm{ml}$ ) with some variability in median anti-dsDNA antibody levels (4.5 to $27.0 \mathrm{lU} / \mathrm{ml}$ ) across dose groups, and an average SELENA SLEDAI score of 2.2 (range 0 to 8 points). There were no significant differences between treatment groups in terms of demographics, baseline disease duration, serology, or manifestations. Eighty per cent of patients were on an immunosuppressive agent, and there were no significant differences in the distribution of patients who were on mycophenolate, prednisone, or methotrexate (Table 2). However, there were more patients in the placebo group $(38 \%)$ compared with the belimumab-treated group (12\%) who were on azathioprine $(P=0.04)$. Thirty-six patients were randomly assigned to receive a single dose of study agent and 34 to receive two doses 21 days apart. All patients completed the study per protocol.

\section{Safety}

Overall, AEs were reported in 12 (92\%) patients treated with placebo and $55(97 \%)$ patients treated with belimumab (Table 3). The majority of AEs were mild to moderate in severity, and the incidence of AEs was similar in the placebo and belimumab (single and double dose) treatment groups. There was no increase in the incidence of infections in the belimumab groups (37\% for all patients treated with active agent versus $62 \%$ for placebo), and only one infection (tinea pedis) was reported to be possibly related to study agent. The most common AEs in patients treated with belimumab were arthralgia $(26 \%)$, headache $(21 \%)$, rash $(21 \%)$, diarrhea $(18 \%)$, and nausea (18\%). Although diarrhea and rash did not occur in the 13 patients who received placebo, these events were generally mild to moderate and were often felt to be unrelated to study drug. Furthermore, dose-dependent trends in those treated patients who developed diarrhea or rash were not observed. The most common AEs in patients treated with placebo were arthralgia (31\%), nausea (31\%), upper respiratory tract infection (15\%), and joint swelling (15\%). The frequency of AEs did not change with increasing doses of belimumab. Overall, there was no significant difference in the incidence of specific AEs between the belimumab groups and placebo.

The majority of AEs were considered not related or probably not related to study agent. In addition, there were no significant differences between placebo-treated and belimumabtreated groups in the incidence of grade 3 or 4 laboratory or hematologic toxicities (Table 4). Frequencies of hematologic or laboratory abnormalities did not vary with increasing dose or number of doses of belimumab. There were three patients (two in the $10 \mathrm{mg} / \mathrm{kg}$ double-dose cohort and one in the $4 \mathrm{mg}$ / $\mathrm{kg}$ single-dose cohort) who developed grade 3 neutropenia ( 500 to $970 / \mathrm{mm}^{3}$ absolute neutrophil count [ANC]) at one or two time points (days 14 or 63 ) during the study. The occurrences of neutropenia were not considered AEs because repeat complete blood counts within 1 week showed ANC to be returning to within the reference range or improving to mild or grade 1 severity. The patient (10 $\mathrm{mg} / \mathrm{kg}$ double dose) with an ANC of $500 / \mathrm{mm}^{3}$ recovered and was rechallenged on day 23 without recurrence of neutropenia. Two patients in the single-dose cohort (one $4 \mathrm{mg} / \mathrm{kg}$ and one $20 \mathrm{mg} / \mathrm{kg}$ ) developed grade 1 or 2 neutropenia considered AEs. The patients receiving $4 \mathrm{mg} / \mathrm{kg}$ belimumab sustained grade 2 neutropenia $(1,160$ to $1,460 / \mathrm{mm}^{3} \mathrm{ANC}$ ) on days 28 to 84 . The patient receiving $20 \mathrm{mg} / \mathrm{kg}$ belimumab sustained grade 1 neutropenia $(1,720$ to $\left.1,940 / \mathrm{mm}^{3} \mathrm{ANC}\right)$ on days 56 and 84.

Abdominal computed tomography scans with oral contrast revealed no evidence of infections or abdominal abscesses. Two patients developed a human anti-human antibody (HAHA) response. A single patient in the $20 \mathrm{mg} / \mathrm{kg}$ double- 
Patient demographics and disease characteristics by treatment groups

\begin{tabular}{|c|c|c|c|c|c|c|}
\hline \multirow{2}{*}{$\begin{array}{l}\text { Patient demographic or disease } \\
\text { characteristic }\end{array}$} & \multirow[t]{2}{*}{ Placebo $(n=13)$} & \multicolumn{5}{|c|}{ Belimumab } \\
\hline & & $1.0 \mathrm{mg} / \mathrm{kg}(n=15)$ & $4.0 \mathrm{mg} / \mathrm{kg}(n=14)$ & $10 \mathrm{mg} / \mathrm{kg}(n=14)$ & $20 \mathrm{mg} / \mathrm{kg}(n=14)$ & All active $(n=57)$ \\
\hline \multicolumn{7}{|l|}{$\operatorname{Sex}(n[\%])$} \\
\hline Female & $11(85)$ & $15(100)$ & $13(93)$ & $12(86)$ & $13(93)$ & $53(93)$ \\
\hline Male & $2(15)$ & 0 & $1(7)$ & $2(14)$ & $1(7)$ & $4(7)$ \\
\hline \multicolumn{7}{|l|}{$\operatorname{Race}(n[\%])$} \\
\hline White & $10(77)$ & $7(47)$ & $3(21)$ & $8(57)$ & $7(50)$ & $25(44)$ \\
\hline African American & $3(23)$ & $8(53)$ & $11(79)$ & $5(36)$ & $6(43)$ & $30(53)$ \\
\hline Asian & 0 & 0 & 0 & $1(7)$ & $1(7)$ & $2(4)$ \\
\hline Hispanic origin $(n[\%])$ & $4(31)$ & $2(13)$ & $1(7)$ & $5(36)$ & $1(7)$ & $9(16)$ \\
\hline Age (years; median [range]) & 38 (30 to 58 ) & 36 (22 to 56$)$ & 48.5 (23 to 62 & 37 (22 to 61$)$ & 38.5 (23 to 80$)$ & 39 (22 to 80$)$ \\
\hline $\begin{array}{l}\text { Duration of SLE (years; median } \\
\text { [range]) }\end{array}$ & $5.3(0.4$ to 15.3$)$ & 3.4 (0.4 to 13$)$ & $8.7(0.4$ to 37.7$)$ & 6.3 (1.8 to 20.8$)$ & $8.0(0.3$ to 29.4$)$ & $6.9(0.3$ to 37.7$)$ \\
\hline $\begin{array}{l}\text { SELENA SLEDAI score (median } \\
\text { [range]) }\end{array}$ & 4 (0 to 4$)$ & 2 (0 to 6$)$ & 0 (0 to 5$)$ & 2 (0 to 8 ) & 2 (0 to 4$)$ & 2 (0 to 8 ) \\
\hline ANA $\geq 1: 40$ at baseline $(n[\%])$ & $12(92)$ & $13(87)$ & $14(86)$ & $13(93)$ & $13(93)$ & $53(93)$ \\
\hline $\begin{array}{l}\text { Anti-dsDNA antibody (IU/ml; } \\
\text { median [range]) }\end{array}$ & 9.5 (4.0 to 162.5$)$ & 6.0 (4.0 to 65.5$)$ & 4.5 (4.0 to 24.0 ) & 27.0 (4.0 to 257.0$)$ & $5.0(4.0$ to 729.0$)$ & 6.5 (4.0 to 729.0$)$ \\
\hline \multicolumn{7}{|l|}{$\begin{array}{l}\text { Manifestations at the time of SLE } \\
\text { diagnosis }(n[\%])\end{array}$} \\
\hline Antinuclear antibody & $13(100)$ & $14(93)$ & $14(100)$ & $14(100)$ & $13(93)$ & $55(97)$ \\
\hline Immunologic disorder & $12(92)$ & $12(80)$ & $12(86)$ & $14(100)$ & $12(86)$ & $50(88)$ \\
\hline Arthritis & $12(92)$ & $14(93)$ & $11(79)$ & $12(86)$ & $12(86)$ & $49(86)$ \\
\hline Hematologic disorder & $7(54)$ & $14(93)$ & $9(64)$ & $7(50)$ & $8(57)$ & $38(67)$ \\
\hline Malar rash & $6(46)$ & $8(53)$ & $5(36)$ & $12(86)$ & $8(57)$ & $33(58)$ \\
\hline Photosensitivity & $7(54)$ & $7(47)$ & $6(43)$ & $9(64)$ & $8(57)$ & $30(53)$ \\
\hline Serositis & $6(46)$ & $4(27)$ & $8(57)$ & $7(50)$ & $8(57)$ & $27(47)$ \\
\hline Oral ulcers & $8(62)$ & $10(67)$ & $6(43)$ & $6(43)$ & $5(36)$ & $27(47)$ \\
\hline Renal disorder & $4(31)$ & $2(13)$ & $4(29)$ & $6(43)$ & $4(29)$ & $16(28)$ \\
\hline Discoid rash & $3(23)$ & $1(7)$ & $5(36)$ & $4(29)$ & $2(14)$ & $12(21)$ \\
\hline Neurologic disorder & 0 & $3(20)$ & $1(7)$ & $1(7)$ & $1(7)$ & $6(11)$ \\
\hline
\end{tabular}

ANA, antinuclear antibody; SLE, systemic lupus erythematosus; SELENA, Safety of Estrogens in Lupus Erythematosus National Assessment; SLEDAI, Systemic Lupus Erythematosus Disease Activity Index.

dose cohort (on concomitant mycophenolate mofetil and prednisone) developed detectable, non-neutralizing HAHA only on day 77 . The other patient in the $1 \mathrm{mg} / \mathrm{kg}$ single dose cohort (on concomitant prednisone) had detectable neutralizing HAHA on days 14 to 56 .

Ten patients (one placebo and nine belimumab) experienced a grade 3 (severe) $A E$, and one patient (belimumab) experienced a grade 4 (potentially life-threatening) AE of thrombocytopenia (Table 4), which was considered probably not related to the study agent. Most events were considered not related or probably not related to study agent. Grade 3 urticaria with chest pain was reported in one patient with a prior history of drug-induced urticaria during the administration of a $20 \mathrm{mg} / \mathrm{kg}$ single dose. The infusion was discontinued approximately 40 minutes after initiation, and the urticaria and chest pain resolved with two doses of intravenous diphenhydramine.

Six patients (one placebo and five belimumab) developed eight serious AEs, none of which were considered related to study agent. Patients in the belimumab single-dose cohorts reported diarrhea, dehydration, and sinus headache (one patient), staphylococcal cellulitis (one patient), and angioedema (one patient). Patients in the belimumab doubledose cohorts reported chest pain (one patient) and pancreatitis (one patient), whereas a patient in the placebo cohort 
Arthritis Research \& Therapy Vol 10 No 5 Furie et al.

Table 2

Frequency of use of immunosuppressive agents during the study

\begin{tabular}{|c|c|c|c|c|c|c|}
\hline \multirow[t]{2}{*}{ Immunosuppressive drugs } & \multirow[t]{2}{*}{ Placebo $(n=13)$} & \multicolumn{5}{|c|}{ Belimumab } \\
\hline & & $1.0 \mathrm{mg} / \mathrm{kg}(n=15)$ & $4.0 \mathrm{mg} / \mathrm{kg}(n=14)$ & $10 \mathrm{mg} / \mathrm{kg}(n=14)$ & $20 \mathrm{mg} / \mathrm{kg}(n=14)$ & All active $(n=57)$ \\
\hline Prednisone & $9(69)$ & $14(93)$ & $9(54)$ & $10(71)$ & $8(57)$ & $41(72)$ \\
\hline Methotrexate & $2(15)$ & $1(7)$ & 0 & $2(14)$ & $3(21)$ & $6(11)$ \\
\hline Azathioprine & $5(38)$ & $2(13)$ & $2(13)$ & $2(14)$ & $1(7)$ & $7(12)$ \\
\hline Mycophenolate & 0 & $1(7)$ & $1(7)$ & $1(7)$ & $5(36)$ & $8(14)$ \\
\hline None & $3(23)$ & $1(7)$ & $5(36)$ & $3(21)$ & $3(21)$ & $12(21)$ \\
\hline
\end{tabular}

Table 3

Incidence (three or more patients) of adverse events by dose: single-dose and double-dose cohorts combined

\begin{tabular}{|c|c|c|c|c|c|c|}
\hline \multirow[t]{2}{*}{ Adverse event } & \multirow[t]{2}{*}{ Placebo $(n=13)$} & \multicolumn{5}{|c|}{ Belimumab } \\
\hline & & $1.0 \mathrm{mg} / \mathrm{kg}(n=15)$ & $4.0 \mathrm{mg} / \mathrm{kg}(n=14)$ & $10 \mathrm{mg} / \mathrm{kg}(n=14)$ & $20 \mathrm{mg} / \mathrm{kg}(n=14)$ & All active $(n=57)$ \\
\hline Arthralgia & $4(31)$ & $3(20)$ & $2(14)$ & $7(50)$ & $3(21)$ & $15(26)$ \\
\hline Headache & $1(8)$ & $3(20)$ & $3(21)$ & $4(29)$ & $2(14)$ & $12(21)$ \\
\hline Rash & 0 & $4(27)$ & $2(14)$ & $2(14)$ & $4(29)$ & $12(21)$ \\
\hline Diarrhea & 0 & 5 (33) & $1(7)$ & $1(7)$ & $3(21)$ & $10(18)$ \\
\hline Nausea & $4(31)$ & $2(13)$ & $3(21)$ & $2(14)$ & $3(21)$ & $10(18)$ \\
\hline Fatigue & 0 & $1(7)$ & $2(14)$ & $3(21)$ & $1(7)$ & $7(12)$ \\
\hline Back pain & $1(8)$ & 0 & $2(14)$ & $1(7)$ & $3(21)$ & $6(11)$ \\
\hline Joint swelling & $2(15)$ & 0 & $1(7)$ & 0 & $4(29)$ & $5(9)$ \\
\hline Synovitis & $1(8)$ & $2(13)$ & 0 & $3(21)$ & 0 & $5(9)$ \\
\hline Depression & 0 & $3(20)$ & 0 & 0 & 0 & $3(5)$ \\
\hline Infections and infestations & $8(62)$ & $4(27)$ & $8(57)$ & $4(29)$ & $5(36)$ & $21(37)$ \\
\hline Upper respiratory tract infection & $2(15)$ & 0 & $3(21)$ & $1(7)$ & $3(21)$ & $7(12)$ \\
\hline Thrombocytopenia ${ }^{a}$ & 0 & 0 & $1(7)$ & 0 & 0 & $1(2)$ \\
\hline Pancreatitis ${ }^{b}$ & 0 & 0 & 0 & 0 & $1(7)$ & $1(2)$ \\
\hline Cellulitis staphylococcalb & 0 & 0 & 0 & $1(7)$ & 0 & $1(2)$ \\
\hline Sepsis ${ }^{b}$ & $1(8)$ & 0 & 0 & 0 & 0 & 0 \\
\hline $\begin{array}{l}\text { Aspartate aminotransferase } \\
\text { increased }\end{array}$ & 0 & 0 & 0 & 0 & $1(7)$ & $1(2)$ \\
\hline Blood creatinine increased ${ }^{b}$ & 0 & 0 & 0 & 0 & $1(7)$ & $1(2)$ \\
\hline Neutrophil count decreased ${ }^{b}$ & 0 & 0 & 0 & $2(14)$ & 0 & $2(4)$ \\
\hline Dehydration ${ }^{b}$ & 0 & 0 & 0 & 0 & $1(7)$ & $1(2)$ \\
\hline Pain in extremityb & 0 & 0 & $1(7)$ & 0 & 0 & $1(2)$ \\
\hline Headache $^{b}$ & 0 & 0 & 0 & $1(7)$ & 0 & $1(2)$ \\
\hline Sinus headache ${ }^{b}$ & 0 & $1(7)$ & 0 & 0 & 0 & $1(2)$ \\
\hline Angioneurotic edema ${ }^{b}$ & 0 & 0 & $1(7)$ & 0 & 0 & $1(2)$ \\
\hline Urticariab & 0 & 0 & 0 & 0 & $1(7)$ & $1(2)$ \\
\hline
\end{tabular}

Values are expressed as $\mathrm{n}(\%)$. aGrade 4 potentially life-threatening adverse event. ${ }^{\mathrm{b}} \mathrm{Grade} 3$ severe adverse event 
Summary of grade 3 and 4 laboratory and hematologic toxicities

\begin{tabular}{|c|c|c|c|c|c|c|c|}
\hline \multirow[t]{2}{*}{ Parameter } & \multirow[t]{2}{*}{ Grade } & \multirow[t]{2}{*}{ Placebo $(n=13)$} & \multicolumn{5}{|c|}{ Belimumab } \\
\hline & & & $\begin{array}{l}1.0 \mathrm{mg} / \mathrm{kg} \\
(n=15)\end{array}$ & $\begin{array}{l}4.0 \mathrm{mg} / \mathrm{kg} \\
(n=14)\end{array}$ & $\begin{array}{l}10 \mathrm{mg} / \mathrm{kg} \\
(n=14)\end{array}$ & $\begin{array}{l}20 \mathrm{mg} / \mathrm{kg} \\
(n=14)\end{array}$ & $\begin{array}{l}\text { All active } \\
(n=57)\end{array}$ \\
\hline $\begin{array}{l}\text { Activated partial } \\
\text { thromboplastin time }\end{array}$ & 3 & 0 & 0 & $1(7)$ & 0 & $1(7)$ & $2(4)$ \\
\hline Creatinine & 3 & 0 & 0 & 0 & 0 & $1(7)^{a}$ & $1(2)$ \\
\hline Hemoglobin & 3 & 0 & $1(7)$ & 0 & 0 & 0 & $1(2)$ \\
\hline Hyperglycemia & 3 & 0 & $1(7)$ & & 0 & 0 & $1(2)$ \\
\hline Neutropenia & 3 & 0 & 0 & $1(7)^{b}$ & $2(14)$ & 0 & $3(5)$ \\
\hline Thrombocytopenia & 4 & 0 & 0 & $1(7)^{b}$ & 0 & 0 & $1(2)$ \\
\hline \multirow[t]{2}{*}{ Proteinuria } & 3 & 0 & 0 & 0 & $1(7)$ & $1(7)^{a}$ & $2(4)$ \\
\hline & 4 & 0 & 0 & 0 & 0 & $1(7)$ & $1(2)$ \\
\hline \multirow[t]{2}{*}{ Prothrombin time } & 3 & $3(23)^{c}$ & $1(7)^{c}$ & 0 & 0 & 0 & $1(2)$ \\
\hline & 4 & $2(15)^{c}$ & 0 & 0 & 0 & 0 & 0 \\
\hline
\end{tabular}

Values are expressed as $n$ (\%). aOne patient had grade 3 serum creatinine and grade 3 proteinuria. bOne patient with grade 3 neutropenia and grade 4 thrombocytopenia after the first $10-\mathrm{mg} / \mathrm{kg}$ dose was rechallenged at grade 1 neutropenia, without further decline after the second dose. cFour of six patients with grade 3 or 4 prothrombin time reported concomitant warfarin use, including the two patients with grade 4 prothrombin time.

developed sepsis (one patient). There was no significant difference in the incidence of severe or serious AEs between patients treated with placebo and those treated with belimumab. There were no deaths during the study.

\section{Pharmacokinetics}

Following intravenous administration, serum belimumab concentrations declined in a bi-exponential manner, with a mean distribution phase half-life of 1.0 to 2.2 days and a mean terminal elimination half-life of 8.5 to 14.1 days (Table 5 and Figure 1). Belimumab was distributed to tissues with a mean steadystate volume of distribution ranging from 69 to $112 \mathrm{ml} / \mathrm{kg}$, representing approximately twice the mean initial volume of distribution, which ranged from 40 to $57 \mathrm{ml} / \mathrm{kg}$. The mean clearance after a single intravenous dose was approximately 7 $\mathrm{ml} /$ day per $\mathrm{kg}$ for all four cohorts, which is much less than the glomerular filtration rate, indicating that renal clearance is not a major component of belimumab clearance. Drug accumulation for maximum serum drug concentration averaged $9 \%$ when two doses of $4.0,10$, or $20 \mathrm{mg} / \mathrm{kg}$ were administered 21 days apart, which was as expected on the basis of the mean terminal elimination half-life of 9.6 to 14.1 days for those cohorts. There were no significant differences in pharmacokinetic parameters between single-dose and double-dose cohorts. Concomitant use of immunosuppressants, hydroxychloroquine, and/or prednisone during the study had no significant effects on belimumab pharmacokinetics (data not shown). Overall, belimumab pharmacokinetics were linear across the 1.0 to $20 \mathrm{mg} / \mathrm{kg}$ dose range, except in the two patients who developed anti-belimumab antibody responses. In these patients, the observed belimumab serum concentra- tions were 2 -fold to 3.5 -fold lower than the predicted values at the time points when anti-belimumab antibodies were detected.

\section{Biologic activity}

In general, the percentage reduction in CD20+ B cells was greater in patients treated with belimumab than in those treated with placebo (Figure 2). The median CD20+ B-cell count and percentage of lymphocytes at baseline were similar in the placebo (159 cells $/ \mathrm{ml}$ and $13.5 \%$ [range $2 \%$ to $36 \%$ ], respectively) and belimumab (176 cells $/ \mathrm{ml}$ and $13.5 \%$ [range $2 \%$ to $51 \%$ ], respectively) treatment groups. Baseline CD $20^{+}$ B-cell and CD138+ plasmacytoid cell count data were not available for one patient in the $4.0 \mathrm{mg} / \mathrm{kg}$ single-dose belimumab cohort. Compared with placebo, a significantly greater reduction in median percentage of $\mathrm{CD}^{2} \mathrm{O}^{+} \mathrm{B}$ cells was observed in the combined group of patients treated with either a single dose of belimumab (day 42: $P=0.0042$; and day 84: $P=0.0036$ ) or two doses of belimumab (day 105: $P=$ $0.0305)$. The median reduction from baseline in $\mathrm{CD} 20^{+} \mathrm{B}$ cells at day 84 for the single-dose cohorts ranged from $11 \%$ to $47 \%$, whereas a $23 \%$ increase was observed in the placebo group. In the double-dose cohorts, the median reduction in CD20+ $\mathrm{B}$ cells at day 105 ranged from $27 \%$ to $43 \%$, whereas a $5 \%$ increase was observed in the placebo group. When patients with baseline values of $5 \% \mathrm{CD}^{2} \mathrm{O}^{+}$cells or greater were pooled across all cohorts $(n=65)$, the overall treatment effect was significant at 42,56 , and 84 days after the last dose $(P<0.01$ for each). Patients on belimumab and mycophenolate mofetil $(n=8)$ had statistically significant differences in CD20 ${ }^{+} \mathrm{B}$ cells at some time points compared with those $(n=$ 


\section{Figure 1}
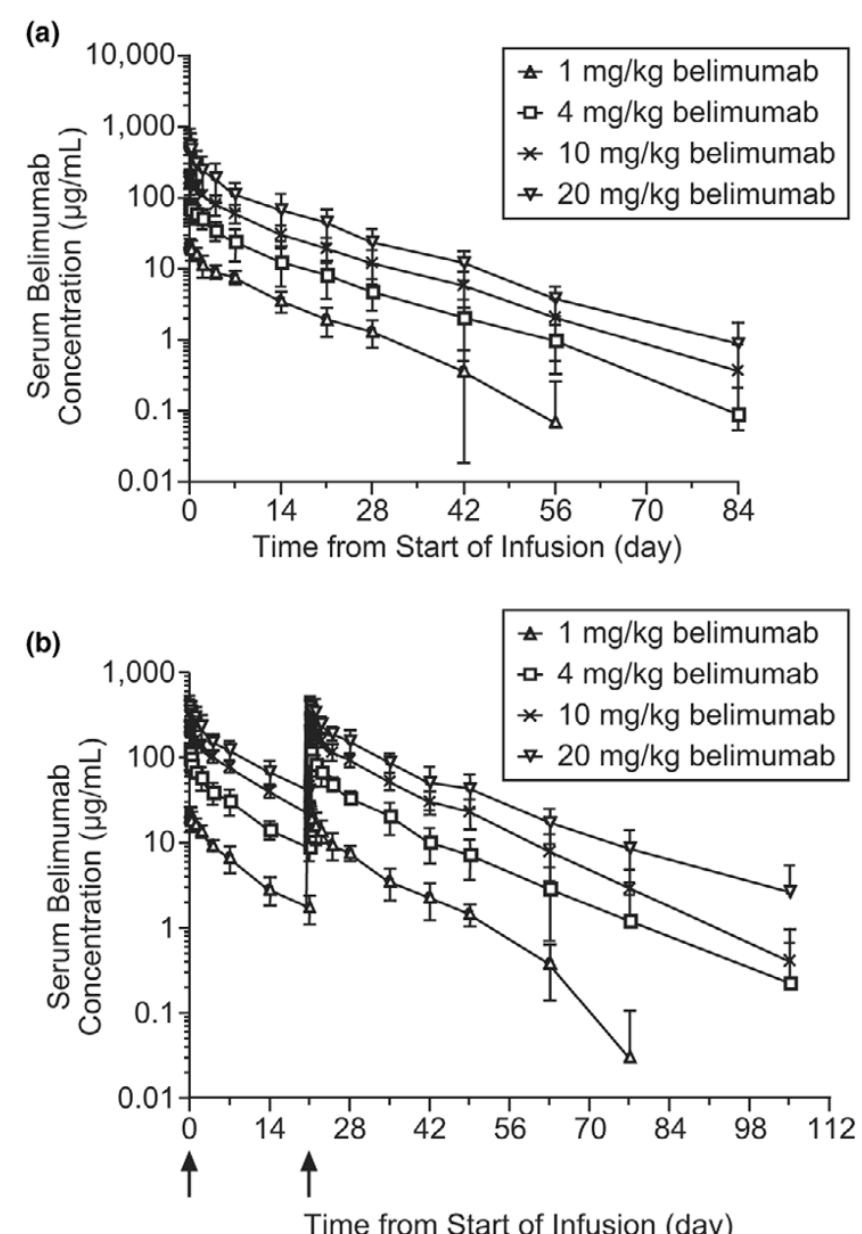

Belimumab concentrations. (a) Concentrations in the single-dose cohort. (b) Concentrations in the double-dose cohort. Arrows indicate time of belimumab administration. Values are expressed as mean \pm standard deviation.

49) on belimumab but not mycophenolate; however, the effects were not consistent throughout the study.

At baseline, the median CD138+ plasmacytoid cell count and percentage of lymphocytes in the placebo group and combined group of patients treated with belimumab was 32 cells/ $\mathrm{ml}$ and $2.5 \%$, respectively. The median change from baseline in $\mathrm{CD} 138^{+}$plasmacytoid cells at day 84 for the single-dose cohorts ranged from a $2.5 \%$ increase in the $1.0 \mathrm{mg} / \mathrm{kg}$ group to a $1.5 \%$ decrease in the $10 \mathrm{mg} / \mathrm{kg}$ group. In contrast, a $4.5 \%$ increase in CD138+ plasmacytoid cells was observed in the placebo group. The overall treatment effect was statistically significant in favor of belimumab for the single-dose cohorts only $(P=0.0226)$.

Forty-four per cent of patients had elevations of anti-dsDNA antibody concentrations (normal $<10 \mathrm{IU} / \mathrm{ml}$ ) at baseline; the median baseline concentration of anti-dsDNA antibody was $22.0 \mathrm{IU} / \mathrm{ml}$ for patients treated with placebo and $27.5 \mathrm{IU} / \mathrm{ml}$ for patients treated with belimumab. Overall, the percentage change from baseline in anti-dsDNA antibody levels was not significantly different for the single-dose or double-dose cohorts compared with placebo. However, a subset analysis of 31 belimumab-treated patients with anti-dsDNA antibody levels $10 \mathrm{IU} / \mathrm{ml}$ or greater at baseline revealed significant changes from 28 to 56 days after the last dose across all cohorts $(P<0.05$; Figure 3$)$. Pair-wise comparison analyses confirmed that changes in anti-dsDNA antibodies in the 20 $\mathrm{mg} / \mathrm{kg}$ dose group were statistically different from placebo at 28,42 , and 56 days after the last dose $(P<0.01$ for each comparison). Of the three patients treated with belimumab who had exceedingly high anti-dsDNA antibody values $(>200$ $\mathrm{IU} / \mathrm{ml}$ ) at baseline, two had a decrease in anti-dsDNA antibody levels of more than $90 \%$ by the end of the study.

The percentage decrease in serum immunoglobulins tended to be greater in patients treated with belimumab (maximal median decrease over time for all doses combined was about $9 \%$ for $\lg$, about $11 \%$ for $\lg \mathrm{A}$, about $16 \%$ for $\lg \mathrm{M}$, and about $24 \%$ for $\lg$ E) compared with those treated with placebo; however, this trend did not achieve statistical significance. There were three patients (20 mg/kg double dose) whose screening and baseline $\operatorname{lgG}$ levels decreased from within the reference range $(680$ to $1,445 \mathrm{mg} / \mathrm{dl})$ to below the lower limit of normal over 105 days (patient 1: 694 [baseline] to 527 [day 77] and 510 [day 105]; patient 2: 762 [baseline] to 651 [day 21] and 650 [day 105]; and patient 3: 809 [baseline] to 677 [day 105]). There were three patients (one receiving $4 \mathrm{mg} / \mathrm{kg}$ double dose, one receiving $1 \mathrm{mg} / \mathrm{kg}$ single dose, and one in placebo) whose screening and baseline lgM levels (38 to $45 \mathrm{mg} /$ dl) decreased from within the normal reference range (33 to $248 \mathrm{mg} / \mathrm{dl}$ ) to below (26 to $31 \mathrm{mg} / \mathrm{dl}$ ) at different time points between days 14 and 77 . None of the patients with normal screening and baseline $\lg A$ levels (70 to $407 \mathrm{mg} / \mathrm{dl}$ ) dropped to below the normal range. Those patients $(n=13)$ with $\lg E$ levels above the reference range $(>120 \mathrm{IU} / \mathrm{ml})$ had a decline of approximately $16 \%$ at days 77 and 84 . None of the reductions in immunoglobulin isotypes were considered to be an $\mathrm{AE}$ by the principal investigators. There were no significant changes in $\mathrm{C} 4$ or $\mathrm{C} 3$ across treatment groups.

\section{Clinical activity}

The median baseline SELENA SLEDAI score for patients treated with placebo was 4 (range 0 to 4 ), with $33 \%$ of patients scoring 0 . For patients treated with belimumab, the median baseline SELENA SLEDAI score was 2 (range 0 to 8 ), with $37 \%$ of patients scoring 0 . Overall, there was a trend toward reduced SELENA SLEDAI scores in both belimumab and placebo groups. Changes in SELENA SLEDAI scores over time stratified according to the baseline SELENA SLEDAI score $(\geq 4$ or $<4$ ) for single- and double-doses are shown in Figure 4. Analysis revealed that the subgroup of patients with an SELENA SLEDAI score of 4 or greater had a median reduction of approximately 2 points 28 days after the last dose of 
Pharmacokinetics parameters by dose levels following single and double doses of belimumab

Pharmacokinetic

parameter

(mean \pm SD)
Belimumab dose and number of patients per cohort

\begin{tabular}{|c|c|c|c|c|c|c|c|c|}
\hline & $\begin{array}{l}\text { Cohort } 1(1.0 \\
\mathrm{mg} / \mathrm{kg} ; n=7)^{\mathrm{a}}\end{array}$ & $\begin{array}{l}\text { Cohort } 2(4.0 \\
\mathrm{mg} / \mathrm{kg} ; n=7)\end{array}$ & $\begin{array}{l}\text { Cohort } 3(10 \\
\mathrm{mg} / \mathrm{kg} ; n=7)\end{array}$ & $\begin{array}{l}\text { Cohort } 4(20 \\
\mathrm{mg} / \mathrm{kg} ; n=6)^{\mathrm{b}}\end{array}$ & $\begin{array}{l}\text { Cohort } 5(1.0 \\
\mathrm{mg} / \mathrm{kg} ; n=6)\end{array}$ & $\begin{array}{l}\text { Cohort } 6(4.0 \\
\mathrm{mg} / \mathrm{kg} ; n=7)\end{array}$ & $\begin{array}{l}\text { Cohort } 7 \text { (10 } \\
\mathrm{mg} / \mathrm{kg} ; n=7)\end{array}$ & $\begin{array}{l}\text { Cohort } 8(20 \\
\mathrm{mg} / \mathrm{kg} ; n=6)\end{array}$ \\
\hline $\mathrm{C}_{\max }(\mu \mathrm{g} / \mathrm{ml})$ & $22.3 \pm 4.2$ & $81.2 \pm 24.6$ & $192.4 \pm 34.9$ & $523.9 \pm 293.7$ & $20.6 \pm 3.0$ & $105.4 \pm 28.0$ & $240.7 \pm 41.7$ & $368.1 \pm 93.5$ \\
\hline $\begin{array}{l}\mathrm{C}_{\max } / \text { dose }(\mathrm{kg} / \\
\mathrm{ml})\end{array}$ & $\begin{array}{l}0.0223 \pm \\
0.0042\end{array}$ & $\begin{array}{l}0.0203 \pm \\
0.0061\end{array}$ & $\begin{array}{l}0.0192 \pm \\
0.0035\end{array}$ & $\begin{array}{l}0.0262 \pm \\
0.0147\end{array}$ & $\begin{array}{l}0.0206 \pm \\
0.0030\end{array}$ & $\begin{array}{l}0.0264 \pm \\
0.0070\end{array}$ & $\begin{array}{l}0.0241 \pm \\
0.0042\end{array}$ & $\begin{array}{l}0.0184 \pm \\
0.0047\end{array}$ \\
\hline $\begin{array}{l}\mathrm{AUC}_{0-\infty} \text { (day } \cdot \mu \mathrm{g} / \\
\mathrm{ml})\end{array}$ & $156 \pm 46$ & $629 \pm 258$ & $1,510 \pm 315$ & $3,384 \pm 1,424$ & $148 \pm 30$ & $729 \pm 145$ & $1,849 \pm 355$ & $3,221 \pm 781$ \\
\hline $\begin{array}{l}\mathrm{AUC}_{0-\infty} / \mathrm{dose} \\
\text { (day } \mathrm{kg} / \mathrm{ml} \text { ) }\end{array}$ & $\begin{array}{l}0.1561 \pm \\
0.0456\end{array}$ & $\begin{array}{l}0.1572 \pm \\
0.0646\end{array}$ & $\begin{array}{l}0.1510 \pm \\
0.0315\end{array}$ & $\begin{array}{l}0.1692 \pm \\
0.0712\end{array}$ & $\begin{array}{l}0.1477 \pm \\
0.0301\end{array}$ & $\begin{array}{l}0.1822 \pm \\
0.0363\end{array}$ & $\begin{array}{l}0.1849 \pm \\
0.0355\end{array}$ & $\begin{array}{l}0.1611 \pm \\
0.0391\end{array}$ \\
\hline$t_{1 / 2, \alpha}$ (day) & $0.96 \pm 0.61$ & $1.49 \pm 0.76$ & $1.84 \pm 0.89$ & $1.27 \pm 0.43$ & $1.87 \pm 0.99$ & $1.23 \pm 0.65$ & $1.03 \pm 0.48$ & $2.21 \pm 1.84$ \\
\hline $\mathrm{t}_{1 / 2, \beta}$ (day) & $8.46 \pm 2.21$ & $9.88 \pm 2.18$ & $10.63 \pm 2.89$ & $11.34 \pm 3.02$ & $9.67 \pm 1.33$ & $9.91 \pm 2.99$ & $9.64 \pm 2.20$ & $14.13 \pm 5.31$ \\
\hline $\mathrm{V}_{1}(\mathrm{ml} / \mathrm{kg})$ & $44.90 \pm 7.12$ & $\begin{array}{l}52.69 \pm \\
18.59\end{array}$ & $\begin{array}{l}52.91 \pm \\
10.20\end{array}$ & $53.17 \pm 40.89$ & $48.95 \pm 8.26$ & $\begin{array}{l}39.61 \pm \\
11.00\end{array}$ & $41.83 \pm 7.63$ & $\begin{array}{l}56.60 \pm \\
15.02\end{array}$ \\
\hline $\mathrm{V}_{\mathrm{ss}}(\mathrm{ml} / \mathrm{kg})$ & $\begin{array}{l}73.29 \pm \\
13.64\end{array}$ & $\begin{array}{l}82.33 \pm \\
22.31\end{array}$ & $\begin{array}{l}86.30 \pm \\
16.77\end{array}$ & $\begin{array}{l}111.67 \pm \\
95.72\end{array}$ & $\begin{array}{l}76.45 \pm \\
19.64\end{array}$ & $\begin{array}{l}69.82 \pm \\
22.72\end{array}$ & $\begin{array}{l}69.21 \pm \\
13.59\end{array}$ & $\begin{array}{l}102.11 \pm \\
30.40\end{array}$ \\
\hline $\begin{array}{l}\mathrm{CL} \text { (ml/day per } \\
\mathrm{kg} \text { ) }\end{array}$ & $7.15 \pm 3.18$ & $7.20 \pm 2.48$ & $6.90 \pm 1.57$ & $7.33 \pm 4.38$ & $7.00 \pm 1.38$ & $5.68 \pm 1.11$ & $5.57 \pm 1.02$ & $6.52 \pm 1.54$ \\
\hline MRT (day) & $11.13 \pm 3.08$ & $12.18 \pm 3.22$ & $13.03 \pm 3.59$ & $14.01 \pm 4.17$ & $10.97 \pm 1.86$ & $12.47 \pm 4.07$ & $12.65 \pm 2.66$ & $16.06 \pm 4.15$ \\
\hline
\end{tabular}

Belimumab was given as a 2-hour infusion. Cohorts 1 to 4 received single doses of belimumab. Cohorts 5 to 8 received two doses of belimumab 21 days apart. In the double dose cohorts, patients who missed doses or displayed positive immunogenicity were excluded. aOne patient in Cohort 1 was anti-belimumab antibody positive on days $14,28,56$, and 84 , and the data were, therefore, excluded from the mean calculation. bOne patient in Cohort 4 did not receive a full dose secondary to urticarial reaction, and serum concentration data from this patient were excluded from the PK analysis. $\mathrm{AUC}_{0}$. ${ }_{\infty}$ area under the serum drug concentration-time curve from time 0 to infinite time; $\mathrm{AUC}_{0-\infty} /$ dose, dose-normalized $\mathrm{AUC} \mathrm{C}_{0-\infty} ; \mathrm{CL}, \mathrm{clearance}_{\mathrm{m}} \mathrm{C}_{\mathrm{m}} \mathrm{AU}$ maximum serum drug concentration; $\mathrm{C}_{\max }$ /dose, dose-normalized $\mathrm{C}_{\max } ; \mathrm{MRT}$, mean residence time; $\mathrm{SD}$, standard deviation; $\mathrm{t}_{1 / 2, \alpha}$, elimination half-life for the distribution phase; $t_{1 / 2, \beta}$, elimination half-life for the terminal phase; $V_{1}$, volume of distribution for the central compartment; $V_{s s}$, volume of distribution at steady state.

belimumab; however, this trend reversed over the next two visits. The use of azathioprine or other immunosuppressive therapy at baseline or whether a patient was ANA positive (ANA $\geq 1: 40$ ) or negative at baseline did not significantly influence SELENA SLEDAI score responses in either belimumab or placebo groups (data not shown). Overall, there were no significant differences between belimumab and placebo treatment groups in SELENA SLEDAl scores or flare rates, as defined by the SLE Flare Index.

The median baseline PGA scores, which ranged from 0.1 to 0.7 across all treatment groups in both cohorts, did not significantly change at any time point. Likewise, there were no significant differences among treatment groups in either absolute change or percentage change in any of the individual or combined scales of the SF-36 Health Survey. In addition, analysis of PGA and SF-36 Physical Component Score, stratified according to the baseline SELENA SLEDAI score $(\geq 4$ or $<4)$ for single dose and double dose, did not reveal any significant changes in these parameters over 84 and 105 days of the study (Figures 5 and 6). The use of azathioprine or other immunosuppressive therapy at baseline or whether a patient was ANA positive (ANA $\geq 1: 40$ ) or negative at baseline did not sig- nificantly influence PGA or SF-36 responses in either belimumab or placebo groups (data not shown).

\section{Discussion}

B cells play a prominent role in the pathogenesis of SLE, based on their ability to present antigen, secrete inflammatory cytokines, and produce autoantibodies. Therefore, B-cell depletion therapy for SLE has been an area of significant interest. Several treatment strategies that directly or indirectly affect $B$ cells were recently investigated, including those that target BLyS, CD20, CD22 and CD154, and BLyS receptors [24,25].

CD40, a member of the TNF receptor superfamily, plays an important role in T-cell-mediated B-cell activation. Cross-linking of B-cell CD40 with CD154 (CD40 ligand), which is expressed on T cells, induces B-cell proliferation [26]. Concentrations of soluble CD154 have been reported to be significantly higher in patients with SLE than in control patients [27]. Early studies in SLE murine models suggested that blocking the interaction between CD40 and CD154 reduced nephritis and anti-dsDNA antibodies, leading to improved survival [2830]. Furthermore, an anti-CD154 antibody, IDEC-131 (a 
Figure 2
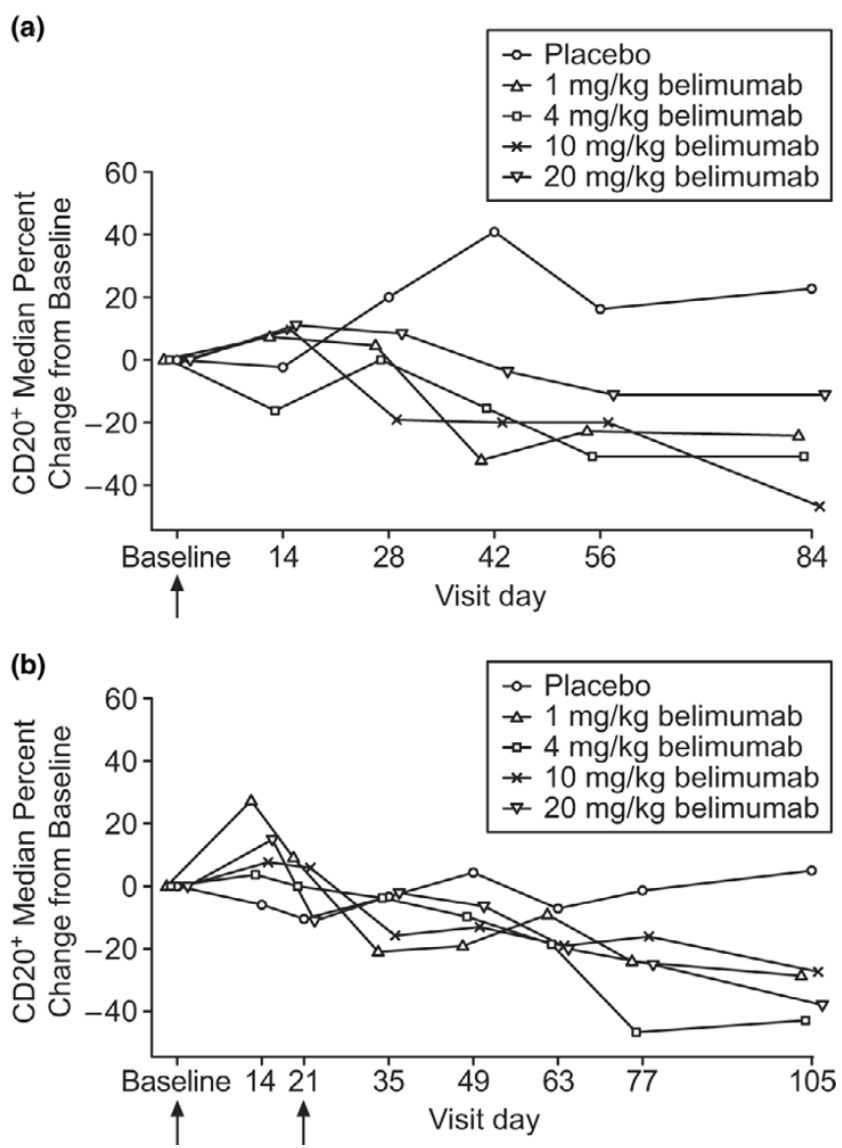

Changes in $\mathrm{CD}^{2} \mathrm{O}^{+} \mathrm{B}$ cells. Median percentage change from baseline in $\mathrm{CD} 2 \mathrm{O}^{+} \mathrm{B}$ cells in (a) single-dose cohorts and (b) double-dose cohorts. Arrows indicate time of belimumab administration.

humanized antibody that blocks CD40-CD154 interactions [31]), was well tolerated in a phase II study conducted in 85 patients with mild-to-moderate SLE [32]; however, it failed to meet the primary efficacy end-point, namely a reduction in SLEDAl score at 20 weeks after six infusions of IDEC-131 ranging from 2.5 to $10 \mathrm{mg} / \mathrm{kg}$. A short course of another antiCD154 antibody, BG9588, resulted in reductions in antidsDNA antibodies, increased C3 concentrations, and decreased hematuria in patients with proliferative lupus nephritis, suggesting that the drug has an immunomodulatory effect [33]. In a subset of this cohort, blockade of CD40 ligand with BG9588 markedly increased the frequency of IgG-producing $B$ cells and IgG anti-DNA antibody producing $B$ cells in the peripheral blood of treated patients. Development of this drug was suspended because of concerns about its prothrombotic effects [33].

Rituximab is a chimeric mouse-human $m A b$ that is specific for CD20 and is currently approved for the treatment of patients with non-Hodgkin's B-cell lymphoma and patients with rheumatoid arthritis who have exhibited an inadequate response to at least one TNF antagonist [34]. Several studies have investi-
Figure 3

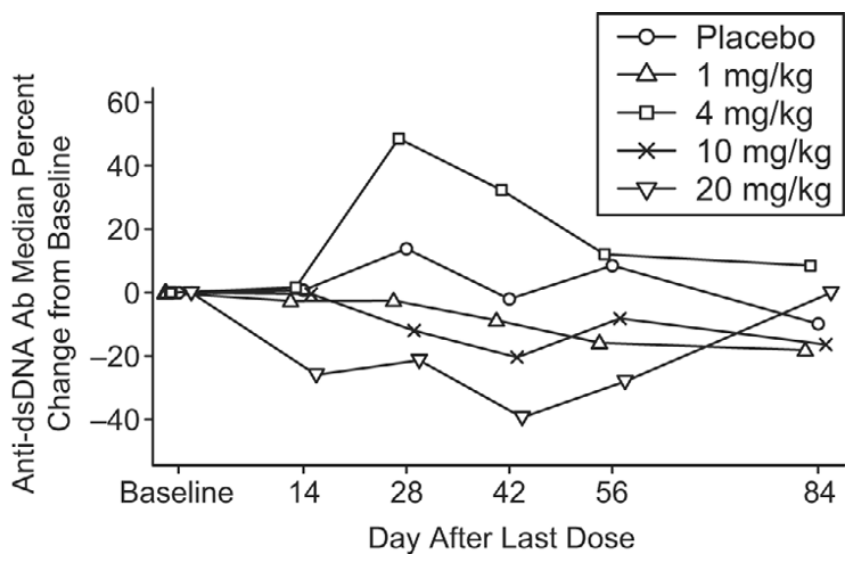

Change in anti-dsDNA antibodies. Mean percentage change from baseline in 31 patients whose anti-dsDNA antibody levels were $10 \mathrm{lU} /$ $\mathrm{ml}$ or greater. dsDNA, double-stranded DNA.

gated rituximab in the treatment of SLE [35-38]. Recently, in two dose-escalation studies of 48 patients with SLE, rituximab therapy resulted in B-cell depletion and improved disease activity $[35,37]$. Rituximab generally appeared to be safe, although 12 out of 42 patients had documented human antichimeric antibody responses [37,38]. Two studies [37,39] have also demonstrated the safety of rituximab in the treatment of patients with lupus nephritis. Similarly, epratuzumab, a humanized anti-CD22 antibody, appeared to be safe in patients with SLE and resulted in immediate decreases in Bcell levels [40]. Antagonism of BLyS by TACI-Fc receptor or AMG 623 (Fc-peptide fusion protein [peptibody] with binding affinity for BLyS) has been evaluated in phase I SLE trials. Gradual reductions in CD20 B cells and immunoglobulin isotypes, particularly lgM, were observed $[41,42]$.

Although anti-CD20 mAbs and BLyS antagonists both mediate B-cell depletion, recent studies suggest that B-cells targeted by anti-CD20 mAbs are not identical to those targeted by BLyS antagonists $[1,5,6]$. CD20 is expressed on most $B$ cell precursors in the bone marrow, immature B-cells, mature naive $B$-cells and memory B-cells. In contrast, BLyS receptors are not expressed on bone marrow B-cell precursors but are expressed on immature and mature B-cells, memory cells, and plasma cells. A recent study reported that a combination of anti-CD20 mAbs and BLyS antagonists achieved more effective $B$-cell depletion in a murine model than either agent alone [43]. Although treatment with agents such as rituximab results in B-cell depletion and improved disease activity $[35,38]$, development of therapies that target other B-cell populations (for example, belimumab) may play a crucial role in enhancing B-cell depletion in patients with SLE. In addition, after treatment with rituximab in SLE patients, BLyS levels significantly increase after $B$-cell depletion until repopulation with $B$ cells occurs $[25,44]$. 


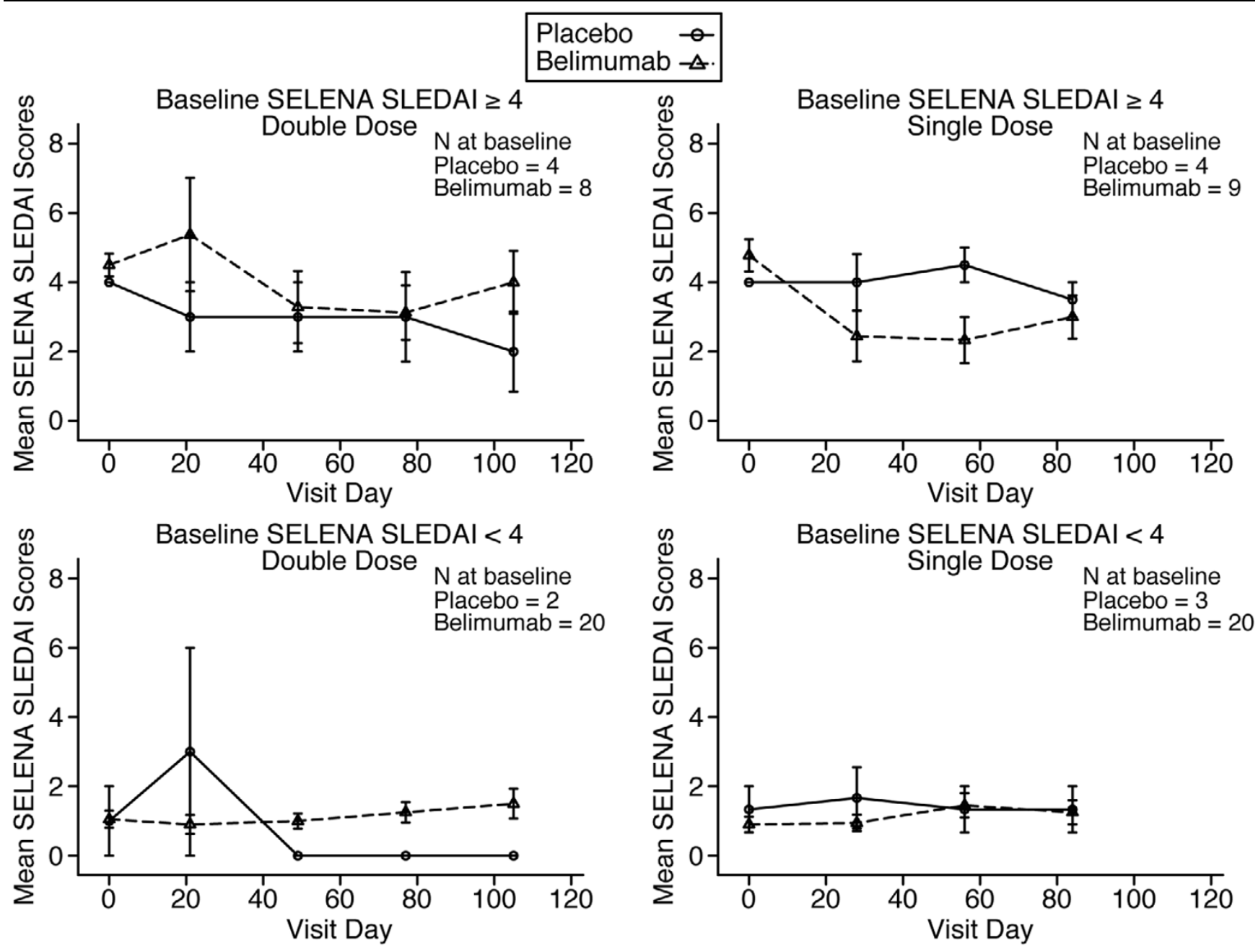

SELENA SLEDAI scores. The SELENA SLEDAI scores in the single-dose and double-dose cohorts over time are presented, stratified by baseline SELENA SLEDAI score $(\geq 4$ or $<4)$. Values are expressed as mean \pm standard error. SELENA, Safety of Estrogens in Lupus Erythematosus National Assessment; SLEDAl, Systemic Lupus Erythematosus Disease Activity Index.

In animal models, BLyS has been shown to be essential not only to the survival of $B$ cells but also to the survival of plasma cells [45]. Belimumab inhibits soluble BLyS activity at subnanomolar concentrations in a murine model [19]. Belimumab, administered to monkeys at 5,15 , or $50 \mathrm{mg} / \mathrm{kg}$ doses every other week, affected peripheral B cells and lymphoid tissues as early as 3 months and 1 month, respectively [20]. Maximum reductions of up to $75 \%$ in CD20+B cells and CD21+ plasmacytoid cells occurred at 13 to 26 weeks [20]. These effects were believed to be related to apoptosis induced by prolonged BLyS depletion and were reversible within 5 months of drug withdrawal.

The pharmacokinetic profile of one or two doses of belimumab was dose proportional and consistent with a fully human mAb. A half-life of 14 days supports dosing every 28 days in future long-term trials. A significantly greater reduction (up to $47 \%$ reduction) in the median percentage of $\mathrm{CD} 2 \mathrm{O}^{+} \mathrm{B}$ cells was observed in patients treated with one or two doses of belimumab compared with placebo. This is consistent with the ability of belimumab to inhibit BLyS biologic activity. Significant reductions in anti-dsDNA antibody were observed 28 to 56 days after the last dose in the subset of patients with levels of $10 \mathrm{IU} / \mathrm{ml}$ or greater at baseline. Immunoglobulin levels, particularly $\lg \mathrm{M}$ and $\lg \mathrm{E}$, were reduced in some belimumab cohorts compared with placebo.

SELENA SLEDAI scores, PGA, SLE Flare Index, and SF-36 Physical Component Score did not significantly improve in this study population. The reasons for this relate to the limited number (one or two) of belimumab infusions, the short duration of the study, the relatively small numbers of patients, and the inclusion of patients with limited or no disease activity (33\% had no disease activity at baseline). However, the demonstrated biologic activity suggests that long-term treatment may produce a clinical response and therapeutic benefit in 


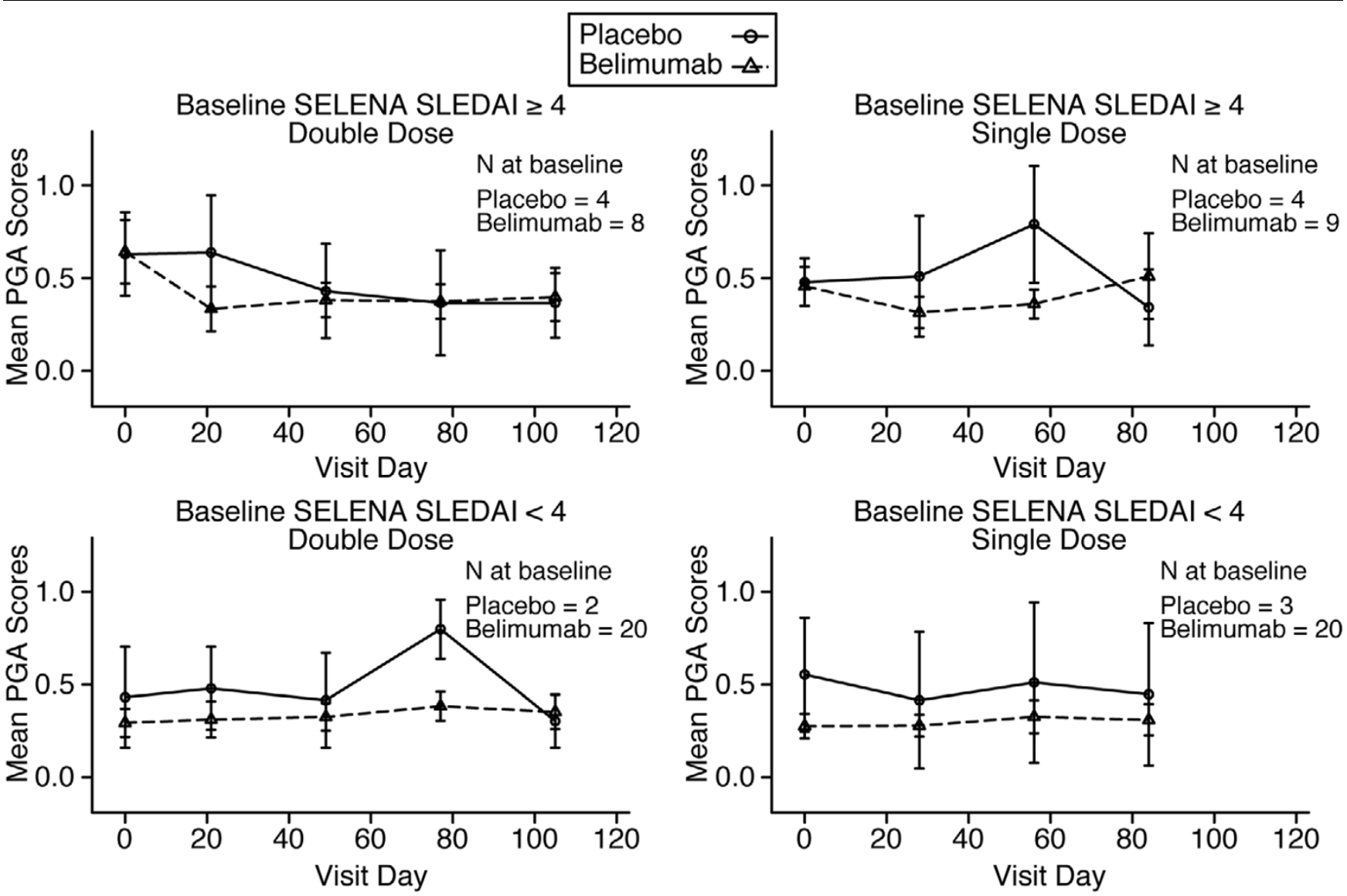

PGA scores. The PGA scores in the single-dose and double-dose cohorts over time are presented, stratified by baseline SELENA SLEDAI score $(\geq 4$ or $<4)$. Values are expressed as mean \pm standard error. SELENA, Safety of Estrogens in Lupus Erythematosus National Assessment; SLEDAI, Systemic Lupus Erythematosus Disease Activity Index; PGA, Physician's Global Disease Assessment.

patients with SLE. If the effects of belimumab in humans are comparable to those in monkeys, then we estimate that the depletion of CD20+ B cells and CD21+ plasmacytoid cells will be $50 \%$ to $80 \%$ within 3 to 6 months of continuous therapy. Significant reduction in B cells was observed in the lymphoid tissue of monkeys after 1 month of treatment but not observed in the peripheral blood until 2 months of continuous therapy [20]. Hence, clinical effects might be delayed until there is a sustained reduction in key B-cell populations. In a phase II SLE study of 449 SLE patients with baseline SELENA SLEDAI scores of 4 or greater (average SELENA SLEDAI score 9.6) treated with 1,4 , and $10 \mathrm{mg} / \mathrm{kg}$ belimumab or placebo plus standard of care SLE therapy, significant improvement in serologically active (ANA $\geq 1: 80$ and/or anti-dsDNA $\geq 30 \mathrm{lU} / \mathrm{ml}$ ) [46] SLE patients in combined belimumab dose groups compared with placebo was seen at week 4 for PGA, week 12 for SF-36, and week 52 for SELENA SLEDAI score $[47,48]$.

The results of this study demonstrate that treatment with one or two intravenous doses of belimumab is safe and well tolerated in patients with mild to moderate SLE. The AE profile of belimumab was comparable to that of placebo, and no serious AEs were deemed related to study agent. Only one patient experienced an infusion reaction, and this reaction responded to treatment with antihistamines. In addition, only one patient developed neutralizing antibodies to belimumab. Because belimumab is a fully human $\mathrm{mAb}$, it is expected that patients are less likely to develop immune responses and hypersensitivity reactions.

\section{Conclusion}

This study demonstrated that belimumab was biologically active in vivo and was safely administered to patients with SLE. These findings supported the initiation of phase II studies investigating the safety and clinical activity of belimumab in patients with SLE and rheumatoid arthritis.

\section{Competing interests}

JZ, WC, and WF were all employees of Human Genome Sciences (HGS) at the time when the trial was conducted. RF, WS, EG, AW, JM, and WC declare research funding for this study provided by HGS. WS, AW, and JM declare they serve 


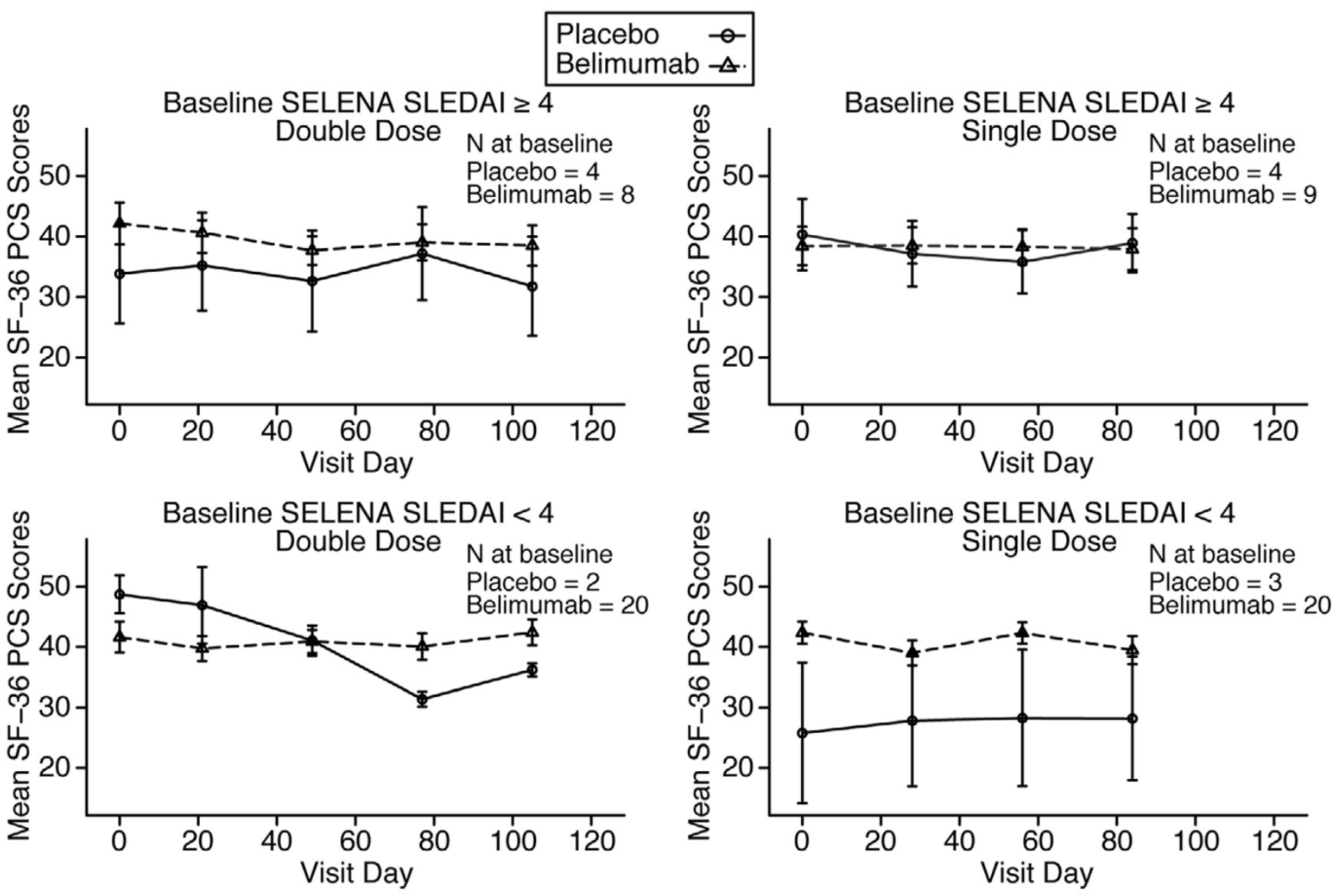

SF-36 PCS scores. The SF-36 PCS scores in single-dose and double-dose cohorts for over time are presented, stratified by baseline SS score ( $\geq 4$ or $<4)$. Values are expressed as mean \pm standard error. PCS, Physical Component Score; SELENA, Safety of Estrogens in Lupus Erythematosus National Assessment; SF-36, 36-item Short Form; SLEDAI, Systemic Lupus Erythematosus Disease Activity Index.

as consultants to HGS. WS also declares research support from HGS and Genentech, Inc., consulting to Genentech, and clinical trial support from Amgen Inc. MB, NM, and JM declare that they have no competing interests.

\section{Authors' contributions}

RF, WS, EG, MB, NM, WC, JM, AW, and WM participated in the trial as principal investigators at their respective institutions. JZ was the lead biostatistician at Human Genome Sciences (HGS). WC was the lead pharmacokineticist at HGS. WF was the lead medical monitor at HGS. All authors contributed to the design of the trial. RF, WS, JZ, and WF drafted the manuscript.

\section{Acknowledgements}

First and foremost, the authors thank the SLE patients for participating in this study. The authors also thank and acknowledge Todd Butler for his management of the clinical trial operations, Drs Todd Riccobene and Blaire Osborn for the work on pharmacokinetic analysis, and the rest of the belimumab project team members from Human Genome Sciences for their contributions to the study. The authors also thank the other principal investigators, including Drs H Belmont, J Block, K Bulpit, G Gilke- son, S Manzi, K Moder, M Petri, R Ramsey-Goldman, W St. Clair, M Dooley, and D Karp.

This study was sponsored by Human Genome Sciences, Inc. (Rockville, MA, USA). The study was also supported in part by NIH grant M01 RR 00043 to the General Clinical Research Center at the University of Southern California Keck School of Medicine, Los Angeles, California, USA.

\section{References}

1. Anolik J, Sanz I, Looney RJ: B cell depletion therapy in systemic lupus erythematosus. Curr Rheumatol Rep 2003, 5:350-356.

2. Criscione LG, Pisetsky DS: $B$ lymphocytes and systemic lupus erythematosus. Curr Rheumatol Rep 2003, 5:264-269.

3. Chan OT, Madaio MP, Shlomchik MJ: The central and multiple roles of B cells in lupus pathogenesis. Immunol Rev 1999, 169:107-121.

4. Jacobi AM, Odendahl M, Reiter K, Bruns A, Burmester GR, Radbruch A, Valet G, Lipsky PE, Dorner T: Correlation between circulating CD27 high plasma cells and disease activity in patients with systemic lupus erythematosus. Arthritis Rheum 2003, 48:1332-1342.

5. Moore PA, Belvedere O, Orr A, Pieri K, LaFleur DW, Feng P, Soppet D, Charters M, Gentz R, Parmelee D, Li Y, Galperina O, Giri J, Roschke V, Nardelli B, Carrell J, Sosnovtseva S, Greenfield W, Ruben SM, Olsen HS, Fikes J, Hilbert DM: BLyS: member of the 
tumor necrosis factor family and B lymphocyte stimulator. Science 1999, 285:260-263.

6. Scapini P, Nardelli B, Nadali G, Calzetti F, Pizzolo G, Montecucco C, Cassatella MA: G-CSF-stimulated neutrophils are a prominent source of functional BLyS. J Exp Med 2003, 197:297-302.

7. Yan M, Marsters SA, Grewal IS, Wang H, Ashkenazi A, Dixit VM: Identification of a receptor for BLyS demonstrates a crucial role in humoral immunity. Nat Immuno/ 2000, 1:37-41.

8. Gross JA, Johnston J, Mudri S, Enselman R, Dillon SR, Madden K, Xu W, Parrish-Novak J, Foster D, Lofton-Day C, Moore M, Littau A, Grossman A, Haugen H, Foley K, Blumberg H, Harrison K, Kindsvogel W, Clegg CH: TACl and BCMA are receptors for a TNF homologue implicated in B-cell autoimmune disease. Nature 2000, 404:995-999.

9. Thompson JS, Bixler SA, Qian F, Vora K, Scott ML, Cachero TG, Hession C, Schneider P, Sizing ID, Mullen C, Strauch K, Zafari M, Benjamin CD, Tschopp J, Browning JL, Ambrose C: BAFF-R, a newly identified TNF receptor that specifically interacts with BAFF. Science 2001, 293:2108-2111.

10. Yan M, Brady JR, Chan B, Lee WP, Hsu B, Harless S, Cancro M, Grewal IS, Dixit VM: Identification of a novel receptor for B lymphocyte stimulator that is mutated in a mouse strain with severe B cell deficiency. Curr Biol 2001, 11:1547-1552.

11. Litinskiy MB, Nardelli $B$, Hilbert DM, He B, Schaffer A, Casali $P$, Cerutti A: DCs induce CD40-independent immunoglobulin class switching through BLyS and APRIL. Nat Immuno/ 2002, 3:822-829.

12. Khare SD, Sarosi I, Xia XZ, McCabe S, Miner K, Solovyev I, Hawkins N, Kelley M, Chang D, Van G, Ross L, Delaney J, Wang L, Lacey D, Boyle WJ, Hsu H: Severe B cell hyperplasia and autoimmune disease in TALL-1 transgenic mice. Proc Natl Acad Sci USA 2000, 97:3370-3375.

13. Mackay F, Woodcock SA, Lawton P, Ambrose C, Baetscher M, Schneider P, Tschopp J, Browning JL: Mice transgenic for BAFF develop lymphocytic disorders along with autoimmune manifestations. J Exp Med 1999, 190:1697-1710.

14. Kayagaki $N$, Yan M, Seshasayee D, Wang $H$, Lee W, French DM, Grewal IS, Cochran AG, Gordon NC, Yin J, Starovasnik MA, Dixit VM: BAFF/BLyS receptor 3 binds the $B$ cell survival factor BAFF ligand through a discrete surface loop and promotes processing of NF-kappaB2. Immunity 2002, 17:515-524.

15. Cheema GS, Roschke V, Hilbert DM, Stohl W: Elevated serum B lymphocyte stimulator levels in patients with systemic immune-based rheumatic diseases. Arthritis Rheum 2001, 44:1313-1319.

16. Zhang J, Roschke V, Baker KP, Wang Z, Alarcon GS, Fessler BJ, Bastian H, Kimberly RP, Zhou T: Cutting edge: a role for B lymphocyte stimulator in systemic lupus erythematosus. $J$ Immunol 2001, 166:6-10.

17. Petri M, Stohl W, Chatham W, McCune WJ, Chevrier M, Ryel J, Recta V, Zhong J, Freimuth W: Association of plasma BLyS levels and disease activity in systemic lupus erythematosus. Arthritis Rheum 2008, 58:2453-2459.

18. Stohl W, Metyas S, Tan SM, Cheema GS, Oamar B, Xu D, Roschke V, Wu Y, Baker KP, Hilbert DM: B lymphocyte stimulator overexpression in patients with systemic lupus erythematosus: longitudinal observations. Arthritis Rheum 2003, 48:3475-3486.

19. Baker KP, Edwards BM, Main $\mathrm{SH}$, Choi GH, Wager RE, Halpern WG, Lappin PB, Riccobene T, Abramian D, Sekut L, Sturm B, Poortman C, Minter RR, Dobson CL, Williams E, Carmen S, Smith R, Roschke V, Hilbert DM, Vaughan TJ, Albert VR: Generation and characterization of LymphoStat-B, a human monoclonal antibody that antagonizes the bioactivities of $B$ lymphocyte stimulator. Arthritis Rheum 2003, 48:3253-3265.

20. Halpern WG, Lappin P, Zanardi , Cai W, Corcoran M, Zhong J, Baker KP: Chronic administration of belimumab, a BLyS antagonist, decreases tissue and peripheral blood B-lymphocyte populations in cynomolgus monkeys: pharmacokinetic, pharmacodynamic and toxicologic effects. Toxicol Sci 2006, 91:586-599.

21. Hochberg MC: Updating the American College of Rheumatology revised criteria for the classification of systemic lupus erythematosus. Arthritis Rheum 1997, 40:1725.

22. Buyon JP, Petri MA, Kim MY, Kalunian KC, Grossman J, Hahn BH, Merrill JT Sammaritano L, Lockshin M, Alarcon GS, Manzi S, Belmont HM, Askanase AD, Sigler L, Dooley MA, Von FJ, McCune WJ,
Friedman A, Wachs J, Cronin M, Hearth-Holmes M, Tan M, Licciardi F: The effect of combined estrogen and progesterone hormone replacement therapy on disease activity in systemic lupus erythematosus: a randomized trial. Ann Intern Med 2005, 142:953-962.

23. Petri M, Buyon J, Kim M: Classification and definition of major flares in SLE clinical trials. Lupus 1999, 8:685-691.

24. Dorner TA, Burmester GR: New approaches of B-cell-directed therapy: beyond rituximab. Curr Opin Rheumatol 2008, 20:263-268.

25. Cambridge G, Isenberg DA, Edwards JC, Leandro MJ, Migone TS, Teodorescu M, Stohl W: B cell depletion therapy in systemic lupus erythematosus: relationships among serum B lymphocyte stimulator levels, autoantibody profile and clinical response. Ann Rheum Dis 2008, 67:1011-1016.

26. Banchereau J, Bazan F, Blanchard D, Briere F, Galizzi JP, van KC Liu YJ, Rousset F, Saeland S: The CD40 antigen and its ligand. Annu Rev Immunol 1994, 12:881-922.

27. Vakkalanka RK, Woo C, Kirou KA, Koshy M, Berger D, Crow MK: Elevated levels and functional capacity of soluble CD40 ligand in systemic lupus erythematosus sera. Arthritis Rheum 1999, 42:871-881.

28. Daikh DI, Finck BK, Linsley PS, Hollenbaugh D, Wofsy D: Longterm inhibition of murine lupus by brief simultaneous blockade of the B7/CD28 and CD40/gp39 costimulation pathways. $\mathrm{J}$ Immunol 1997, 159:3104-3108.

29. Kalled SL, Cutler AH, Datta SK, Thomas DW: Anti-CD40 ligand antibody treatment of SNF1 mice with established nephritis: preservation of kidney function. J Immunol 1998, 160:2158-2165.

30. Wang X, Huang W, Schiffer LE, Mihara M, Akkerman A, Hiromatsu $\mathrm{K}$, Davidson A: Effects of anti-CD154 treatment on B cells in murine systemic lupus erythematosus. Arthritis Rheum 2003, 48:495-506

31. Brams $P$ Black A, Padlan EA, Hariharan K, Leonard J, ChambersSlater K, Noelle RJ, Newman R: A humanized anti-human CD154 monoclonal antibody blocks CD154-CD40 mediated human B cell activation. Int Immunopharmacol 2001, 1:277-294.

32. Kalunian KC, Davis JC Jr, Merrill JT, Totoritis MC, Wofsy D, IDEC131 Lupus Study Group: Treatment of systemic lupus erythematosus by inhibition of $\mathrm{T}$ cell costimulation with antiCD154: a randomized, double-blind, placebo-controlled trial. Arthritis Rheum 2002, 46:3251-3258.

33. Boumpas DT, Furie R, Manzi S, Illei GG, Wallace DJ, Balow JE, Vaishnaw A: A short course of BG9588 (anti-CD40 ligand antibody) improves serologic activity and decreases hematuria in patients with proliferative lupus glomerulonephritis. Arthritis Rheum 2003, 48:719-727.

34. Grillo-Lopez AJ, White CA, Dallaire BK, Varns CL, Shen CD, Wei A, Leonard JE, McClure A, Weaver R, Cairelli S, Rosenberg J: Rituximab: the first monoclonal antibody approved for the treatment of lymphoma. Curr Pharm Biotechnol 2000, 1:1-9.

35. Albert D, Dunham J, Khan S, Stansberry J, Kolasinski S, Tsai D, Pullman-Mooar S, Barnack F, Striebich C, Looney RJ, Luning Prak ET, Kimberly R, Zhang Y, Eisenberg R: Variability in the biological response to anti-CD20 B-cell depletion in SLE. Ann Rheum Dis 2008 in press.

36. Kneitz C, Wilhelm M, Tony HP: Effective B cell depletion with rituximab in the treatment of autoimmune diseases. Immunobiology 2002, 206:519-527.

37. Leandro MJ, Cambridge G, Edwards JC, Ehrenstein MR, Isenberg DA: B-cell depletion in the treatment of patients with systemic lupus erythematosus: a longitudinal analysis of $\mathbf{2 4}$ patients. Rheumatology (Oxford) 2005, 44:1542-1545.

38. Looney RJ, Anolik JH, Campbell D, Felgar RE, Young F, Arend $\sqcup$, Sloand JA, Rosenblatt J, Sanz I: B cell depletion as a novel treatment for systemic lupus erythematosus: a phase I/II doseescalation trial of rituximab. Arthritis Rheum 2004, 50:2580-2589.

39. Sfikakis PP, Boletis JN, Lionaki S, Vigklis V, Fragiadaki KG, Iniotaki A, Moutsopoulos HM: Remission of proliferative lupus nephritis following $B$ cell depletion therapy is preceded by down-regulation of the T cell costimulatory molecule CD40 ligand: an open-label trial. Arthritis Rheum 2005, 52:501-513.

40. Dörner T, Kaufmann J, Wegener WA, Teoh N, Goldenberg DM, Burmester GR: Initial clinical trial of epratuzumab (humanized 
anti-CD22 antibody) for immunotherapy of systemic lupus erythematosus. Arthritis Res Ther 2006, 8:R74.

41. Dall'Era M, Chakravarty E, Wallace D, Genovese M, Weisman M, Kavanaugh A, Kalunian K, Dhar P, Vincent E, Pena-Rossi C, Wofsy D: Reduced B lymphocyte and immunoglobulin levels after atacicept treatment in patients with systemic lupus erythematosus. Arthritis Rheum 2007, 56:4142-4150.

42. Belouski SS, Rasmussen HE, Thomas JK, Ferbas J, Zack DJ: Changes in B cells and B cell subsets induced by BAFF neutralization in vivo [abstract]. Arthritis Rheum 2007, 48:s565.

43. Gong Q, Ou Q, Ye S, Lee WP, Cornelius J, Diehl L, Lin WY, Hu Z, Lu Y, Chen Y, Wu Y, Meng YG, Gribling P, Lin Z, Nguyen K, Tran $T$, Zhang $Y$, Rosen H, Martin F, Chan AC: Importance of cellular microenvironment and circulatory dynamics in $B$ cell immunotherapy. J Immunol 2005, 174:817-826.

44. Vallerskog T, Heimburger M, Gunnarsson I, Zhou W, Wahren-Herlenius M, Trollmo C, Malmstrom V: Differential effects on BAFF and APRIL levels in rituximab-treated patients with systemic lupus erythematosus and rheumatoid arthritis. Arthritis Res Ther 2006, 8:R167.

45. O'Connor BP, Raman VS, Erickson LD, Cook WJ, Weaver LK, Ahonen C, Lin LL, Mantchev GT, Bram RJ, Noelle RJ: BCMA is essential for the survival of long-lived bone marrow plasma cells. J Exp Med 2004, 199:91-98.

46. Petri M, Wallace DJ, Stohl W, McKay J, Stern S, Furie R, McCain A, Ginzler E, Chatham W, Hall L, Migone T, Pineda L, Freimuth W, Chevrier M: SLE patients with active production of anti-nuclear autoantibodies (ANA) have distinct patterns of lupus activity and peripheral B-cell biomarkers compared to ANA negative patients [abstract]. Ann Rheum Dis 2006, 65:356.

47. Furie R, Lisse J, Merrill JT, Petri M, Ginzler E, Aranow C, Weinstein A Strand V, Weisman $\mathrm{MH}$, Diskin $\mathrm{K}$, Fernandez V, Zhong J, Chevrier M, Freimuth W: Multiple SLE disease activity measures in a multi-center phase 2 SLE trial demonstrate belimumab (fully human monoclonal antibody to B-lymphocyte stimulator [BLyS] improves or stabilizes SLE activity [abstract]. Ann Rheum Dis 2006, 65:63.

48. Wallace DJ, Lisse J, StohI W, McKay J, Boling E, Merrill JT, Furie R, Petri M, Ginzler E, Chatham W, Fernandez V, Zhong J, Chevrier M, Freimuth W: Belimumab (Bmab), a fully human monoclonal antibody to B-lymphocyte stimulator (BLyS), shows bioactivity and reduces systemic lupus erythematosus (SLE) disease activity [abstract]. Ann Rheum Dis 2006, 65:62. 